\title{
Opinions of the Teaching Staff at Taibah University About Islamic Education Teacher Preparation Programs in the Light of the Requirements of Intellectual Security
}

\author{
Awadh Zuraiban Al-Johani ${ }^{1}$ \\ ${ }^{1}$ College of Education, Taibah University, Medina, Saudi Arabia \\ Correspondence: Awadh Zuraiban Al-Johani, College of Education, Taibah University, Medina, Saudi Arabia. \\ E-mail: awadzj@hotmail.com
}

Received: January 8, 2021

Accepted: February 21, $2021 \quad$ Online Published: April 25, 2021

doi:10.5539/ies.v14n5p42

URL: https://doi.org/10.5539/ies.v14n5p42

\begin{abstract}
The current study aims to explore the realm of preparing Islamic education teachers in the light of the intellectual security requirements from the point of view of teaching staff at Taibah University. The researcher used the descriptive approach and designed a questionnaire to review the opinions that consisted of two main topics. The first topic is the intellectual security requirements for the academic preparation program (the Specialist Academic Aspect - the Cultural Aspect - the Educational Aspect "Professional") to encounter radicalism and terrorism. The second topic is the proposed concept to encounter the obstacles to fulfill intellectual security requirements in the preparation colleges programs. Each main topic is subdivided into a set of clauses (42 clauses) for the two topics. The study sample consists of (83) teaching staff members at the preparation colleges. The study has been applied to the study sample during the first semester of the academic year 1439 - 1440 A.H. The study findings show the following:

- The first topic achieved (78.55\%) of the opinions of the study sample members about the preparation program of the Islamic Education teachers in the light of the intellectual security requirements for encountering radicalism and terrorism.

- The second topic achieved (93\%) of the opinions of the study sample members about the proposed concept to overcome the obstacles to meet intellectual security requirements in the preparation programs.

- There are no differences of the statistical significance level $(50 .=\infty)$ among the study sample members toward the questionnaire according to the faculty type for the first topic and the tool in general.

- There are no differences of the statistical significance level $(50 .=\infty)$ among the study sample members toward the questionnaire according to the faculty type for the second topic and the tool in general.
\end{abstract}

Keywords: teacher preparation, Islamic education, intellectual security requirements

\section{Introduction}

Today's world experiences a series of changes and developments that encompassed all areas of life, including education, thanks to the enormous scientific and technological revolution and accelerating progress in knowledge and information. Then, there have emerged crucial challenges that require facing and dealing them and interacting with their goals, and responding to their requirements.

Undoubtedly, facing these inevitable challenges is based on a complete conviction of the importance of the teacher's role to face these challenges in achieving a desirable civilizational leap.

Thus, Dahawi and Hussein (2009) point out that these inevitable challenges that require a response to change and interaction with their events. As a result, many societies began to review their educational systems, and the issue of teacher development received special attention, given the multiplicity of roles that a teacher plays, especially in the light of the tremendous changes that have occurred in the end of the $20^{\text {th }}$ Century and those expected to occur in the $21^{\text {st }}$ Century.

Based on the firm belief in the importance of the teacher, preparing the teacher for this profession is one of the most fundamental issues that must be carefully considered, being the cornerstone of the educational learning system. 
The Islamic guidance for teacher education and the requirements for acquiring the skill in raising his students in a sound Islamic manner was the starting point for education policies in the Islamic societies. Teacher education is a continuous process that begins from choice to join teacher preparation institutions and extends to the end of service in teaching. To meet the challenges facing the teacher, accuracy must be provided for his choice of the profession and the integration of aspects of his preparation, and the follow-up of his training during the service, which will help prepare an efficient teacher, adhering to the ethics of the profession, increasing the capability of carrying out educational and teaching role, and meeting the society's needs and aspirations (Al-Ghamdi, 2006).

On this basis, the preparation of the teacher in the light of the demands of development and latest contemporary developments has become one of the most basic and important requirements to meet the needs and future aspirations of the society.

From this standpoint, the teacher preparation colleges in Saudi universities have taken upon themselves the importance of preparing the teacher and qualifying him academically and educationally, and developing all aspects of his personality to be able to face practical life amidst today's requirements and variables. The teacher's role is not limited to transfer of knowledge to learners as was the case in the past. There have emerged new roles for teachers that require that their preparation programs be in line with modern requirements.

For this reason, the need has increased in the present time to pay attention to the teacher and qualify him in the light of the new roles that he should play. A follower of educational literature will find that this interest increases day after day thanks to its importance. There have been rising voices calling for the importance of developing teacher preparation programs in universities in general, and programs for preparing Islamic education teachers in particular. These voices emphasized the necessity of reconsidering the programs of preparation colleges in terms of considering their organization and program structures to comply with the contemporary requirements, and in line with the Arab and Islamic environment, in response to multiple factors imposed by contemporary life (Al-Johani, 2014).

In the light of these new roles for the teacher, the requirements for intellectual security are among the most important basic pillars that any educational institution seeks to achieve. When a teacher is well-prepared before graduation, he is intellectually and behaviorally built to confront any intellectual current or deviation or cultural corruption. Definitely, such preparation is a bulwark for him and for future students as well.

The university is the educational institution most capable of crystallizing and achieving the concept of intellectual security. Therefore, Shaldan (2013) confirms that the university stage represents the peak of awareness, understanding and perception for those who are considered teachers, as they are provided with preventive doses in which the effect on the goodness of the student and his social affiliation is taken into account, which drives them towards the automatic tendency to adhere to the order and instructions. So, it is important to learn how the security of society in general, and its safety in particular, are achieved through psychological and social preparation to adapt to the collective values, hopes, aspirations and behaviors that achieve both security and safety.

Hence there emerged the idea of this current study, aiming to reveal the reality of preparing Islamic education teachers in the light of the requirements of intellectual security to confront extremism and terrorism, from the point of view of the teaching staff at the preparation colleges at Taiba University.

\subsection{The Study Problem}

The problem of the current study centers on answering the following questions:

1) What are the requirements for intellectual security required for the programs of preparing Islamic education teachers to confront extremism and terrorism from the point of view of the teaching staff at the preparation colleges at Taibah University?

2) What is the reality of the programs for preparing Islamic education teachers in the light of the requirements of intellectual security to confront extremism and terrorism from the point of view of the teaching staff at the preparation colleges at Taibah University?

3) What are the proposed solutions to overcome the obstacles that prevent the fulfillment of the requirements of intellectual security in the programs of preparing Islamic education teachers to confront extremism and terrorism from the point of view of the teaching staff at the preparation colleges at Taibah University?

4) Are there statistically significant differences at the level of significance $(\propto=50$.) About the reality of programs for preparing Islamic education teachers in the light of the requirements of intellectual security among members of the study sample, members of the teaching staff at colleges of preparation, due to the college variable? 
5) Are there statistically significant differences at the significance level $(\propto=50$.$) about the proposed solutions$ to overcome the obstacles that prevent the requirements of intellectual security in the programs of preparing Islamic education teachers to confront extremism and terrorism among the study sample members, the teaching staff of the preparation college due to the college variable?

\subsection{The Importance of the Study}

The importance of the study is represented in the following:

1) Directing the attention of decision-makers at the preparation colleges concerned with teacher preparation and qualification, with the need to reconsider his preparation programs in line with the requirements of intellectual security.

2) Directing the attention of the teaching staff at the preparation colleges programs in the following three academic aspects (the specialized - cultural - educational aspect ("professional")) on the need to reconsider their teaching to comply with the requirements of intellectual security.

3) Providing planners and developers of student and teacher preparation and qualification programs at the preparation colleges in the three academic aspects (the specialized - cultural - educational ("professional") aspect) with the requirements of intellectual security and the possibility of adopting these requirements and including them within the objectives and content of the preparation programs' decisions.

4) Providing students with the concepts and requirements of intellectual security and in a way that would benefit them in confronting extremism and terrorism.

5) It helps interested people and researchers by paving the way to them to conduct other studies and research related to the requirements of intellectual security in order to face other issues and challenges of the age.

\subsection{Objectives of the Study}

This current study aims at:

- Knowing the requirements of intellectual security necessary for Islamic education teachers to confront extremism and terrorism.

- Knowing the reality of programs for preparing Islamic education teachers for security requirements from the point of view of teaching staff at preparation colleges at Taibah University.

- Reaching proposed solutions to overcome the obstacles that prevent the fulfillment of the requirements of intellectual security through the programs of preparing Islamic education teachers to confront extremism and terrorism.

- Disclosing whether there are statistically significant differences at the level of significance $(\propto=50$. $)$ about the reality of programs for preparing Islamic education teachers in the light of the requirements of intellectual security among the study sample members of the teaching staff at the preparation colleges due to the college variable.

- $\quad$ Disclosure of whether there are statistically significant differences at the level of significance $(\propto=50$. $)$ about the proposed solutions to overcome the obstacles that prevent the requirements of intellectual security in the programs of preparing Islamic education teachers to confront extremism and terrorism among the members of the study sample, teaching staff at the preparation colleges attributed to college variable.

\subsection{Terminology of Study}

Teacher Preparation (formation): Preparing a student for a successful academic and professional preparation before service at the concerned preparation college, if this preparation is considered the primary industry for him before practicing the teaching profession, and his preparation consists of academic programs provided by preparation colleges. These academic programs consist of three academic aspects (professional - cultural educational aspect) (Shehata et al., 2003).

Security in language: As it was mentioned in the tongue of the Arabs, it came from the word (security) a connection from the words of the same root, which is security, so we find security, honesty and reassurance, security that is against fear, honesty against betrayal, faith against infidelity, and security is safety, oath and safety, which is a guarantee of life and peace and the foundations of civilized existence and peaceful coexistence (Ibn Manzur, 2002).

Intellectual security is idiomatically defined as ensuring the integrity of the human mind from deviation, deviation from moderation in his understanding of religious and political matters and his perception of the universe, leading 
to the preservation of order and stability (Al-Ghafili, 2009).

Requirements of intellectual security are defined as: a set of activities that are carried out by relevant educational institutions to improve students' minds through sound ideas related to religion, politics and culture in the face of ideas that contradict with the correct thought in the Muslim community, with the aim of preparing and shaping a normal, effective personality (Shaldan, 2013). The researcher can adopt this definition procedurally for the current study and measure the reality of preparing Islamic education teachers in the light of the requirements of intellectual security through a questionnaire prepared for this purpose with the following dimensions (agree - agree to some extent - disagree).

There are terms related to intellectual security that must be defined, namely (extremism and terrorism - intellectual deviation - moderation).

Extremism and terrorism are linguistically defined according to the linguistic dictionaries in various languages, whoever is extremist in doing something exceeds the limit of moderation and does not mediate. The same meaning applies to exaggeration, for it is beyond the limit and destiny according to Ibn Manzur's vision, as well as in religion and the matter is exaggerated: exceeded its limit and the inevitable result that these meanings are translated by actions that do not tend to peace and tranquility, but rather appear in what has been termed terror, and what is more like a phrase terror with the same meaning in the English language terror and what it contains in terms of the meanings of intimidation, horror and terror. So, the term linguistic terrorism came from (fear) of a horror that terrifies terrorism and (terror it) that is to fear it and its root (fear) (Al-Hamami, 2009; Al-Badr, 2009).

Extremism is defined from the idiomatic point of view: the person's feeling that he possesses all the truth from what he has a complete conviction of the rightness of what he possesses, which leads him to act in the direction of correcting others and convincing them of his point of view, and if they are not convinced, he resorts to violence, which is the practice of intellectual extremism. That is, it is a means of expressing opinions, feelings, and beliefs, in a manner devoid of emotional balance, and trespassing the concept of moderation (Bahjat, 2009).

Terrorism is idiomatically defined as: Transcending the stage of extremism to another stage that involves imposing opinion or beliefs by force (Abu Yusuf, 2009).

Intellectual Deviation: It is an individual or collective predilection that reflects on the self or on the other, whether the other is an individual or group, and seeks to spread ideas that do not have a reference approved by Sharia or law (Al-Noah, 2011)

\subsection{The Limits of the Study}

The study is determined by the following determinants:

- Objective limits: The current study is limited, within its objective limits, to the opinions of a sample of teaching staff at Preparation Colleges of Islamic Education Teachers at Taibah University, namely the College of Arts and Humanities and the College of Education on the reality of the Islamic Education Teacher Preparation Program in the light of the requirements of intellectual security.

- Spatial boundaries: Taibah University, College of Arts and Humanities, the scientific departments of the specialized and cultural preparation side, and the College of Education with all its concerned departments beside the "professional" educational preparation.

- Time limits: The study tool was applied to its sample during the first semester of the academic year 1441-1442 AH.

\section{Theoretical Framework}

There is no doubt that the emergence of changes occurring in all aspects of life has greatly affected the attributes and characteristics of the modern person, and in response to the requirements of this life and the changes taking place, this matter may require looking at the teacher and how he is prepared. So, the Ministry of Education in the Kingdom of Saudi Arabia has paid great attention to preparing and upgrading the academic and professional level of the teacher, and developing strategies and policies related to his preparation programs that ensure professional development, so that he can become able to keep pace with the successive developments that have affected the objectives of education.

It should be noted here that preparing a teacher in the light of these variables and developments is one of the inevitable matters that necessitate continuous and comprehensive development of all educational institutions, whether that is preparing for the teacher at the preparation colleges or in-service training, in order to be more able to immediately respond to the variables of the amazing developments in all areas, what the rapid changes impose on the goals and requirements of education and the successive changes that entail in its conditions and environment 


\section{(Al-Bilawi, 2008).}

Teacher preparation aims at achieving self and continuous growth, which corresponds to his specialized, professional and cultural academic level in order to achieve his ambition, psychological stability, and professional satisfaction towards the profession that he will practice after graduating from the preparation colleges. A successful teacher is the one who responds to the developments of life around him, and the variables that happen in the human community and the new trends. This requires flexibility, lack of rigidity and the ability of renewal and innovation.

The importance of preparing the teacher is evident from the above. Preparing teachers in the light of the demands of development and developments in the times has become an important basic requirement to meet the needs of and future aspirations of the society.

The needs and requirements of society vary, and perhaps the most important of these societal needs is the need for national security, and here is the reassurance of security that is against fear and terrorism.

It should be noted here that security has become a new concept that goes beyond the concept of traditional and fragmented security in the form of national and regional security, which is limited by the geography of the state, whose attention is focused on providing security requirements in its limited area. So, the concept of security today is completely different from the previous one, as today it has become comprehensive security, which has become national or domestic security, a part of this overall concept (Kenanaonline.com).

Perhaps the emergence of this concept of "comprehensive security" may be due to the developments of the contemporary world, which have made the countries of the world and their societies face fateful and inevitable challenges, giving rise to the search for means of prevention that ensure protection of societies against these challenges, such as organized crimes that emerged from global repercussions and economic and social openness in addition to other crimes such as electronic crimes, organized terrorism, intellectual invasion and others.

It is noteworthy that the term comprehensive security relates to a complete system as well as to interlocking systems that have total interconnectedness, partial independence, and points of convergence and cohesion, because comprehensive security is all connected and we can find many matrices through which the comprehensive security vision is revealed, there is internal security, systematic security, economic security, social security and intellectual security (Al-Sharif, 2013).

With a closer look at these divisions of the types of comprehensive security, we find that intellectual security is one of the most important of these comprehensive types of security, due to the linkage of this type of security with human thought. That is why Al-Harbi (2008) confirms that intellectual security tops the pyramid among other types of security, as it comes first in terms of importance and danger. It is the core and major pillar of security and its importance stems from being a protection of the most important acquisitions and the greatest necessities, which is the identity of the nation. As it stems, its importance is due to its close association with other forms of security. The realization of intellectual security provides an automatic verification of other types of security. "The human being is held captive by his thought and belief, and what man's action, attitude and behavior in real life is but an echo of his thought and reason".

The concept and importance of intellectual security:

There have been many opinions about the concepts of "intellectual security" and perhaps one of the most important of these definitions is that of Mbarki (2009). Idiomatically, the concept of intellectual security is the activity and joint measures between states and society to avoid individuals and groups of ideological, intellectual or psychological defects that cause the deviation of behavior, ideas and ethics from the seriousness of the right or a reason to fall into perils.

Kafi (2009) defines it as "that the integrity of thought in its choices and attitudes in life is the result of a sound mental and legal construction," and that it is the result of "fortifying the thought of members of society from deviant ideas threatening its security and prosperity.

Intellectual security in Islam is of great importance for it is a thought and a heavenly message. A result is the unity of belief, thought and behavior. It is commitment and moderation. It is the protection of the Muslim human mind, thought and opinion within the framework of the basic constants, being a distinct thought from all other ideas, as it derives its roots from the nation's belief, axioms and constants, and the real entrance to creativity, development and growth for the civilization and culture of society. It explores how to handle a crime in general and crimes of violence in particular. It is a thought distinct from all other ideas, because it is a thought that requires protection of thought itself from deviation (Al-Sudais, 2009; Mbarki, 2009). 
This concept of "intellectual security" has repercussions and causes that have led to attention to this type of security, due to the many temptations and challenges that face the nation's youth today. Young people are most vulnerable to many of the temptations and suspicious calls that drag them into intellectual deviation that is a major cause of the spread of the hordes of terrorism and the ideology of extremism. This requires that they must be protected from any ideological and behavioral deviation that drags them into extremism.

Emergence of Intellectual Security:

God Almighty has given man many yes, and that of the most important of these graces is the grace of the mind, which God devoted to man to manage and reflect on God's creatures. The Almighty said: (The ones who remember Allah, upright and seated and on their sides, and meditate upon the creation of the heavens and the earth: "Our Lord, in no way have You created this untruthfully. All Extolment be to You! So protect us from the torment of the Fire!) (The Family of Imran: 191), (And He has subjected to you whatever is in the heavens and whatever is in the earth, all together from Him. Surely in that are signs for a people who meditate.) (The Crouching: 13).

Perhaps those who consider the meaning of these two verses will find that the Holy Qur'an directs the mind toward thinking and contemplating the universe and contemplating its manifestations, and then preserving the mind from any intellectual deviation is a safety for it from falling into error, just as preserving the mind is a directive of human behavior towards good and straightness.

Whoever contemplates finds that in the event that this contract deviates from the right and correct thinking, it will lead to insecurity and stability, and this is the first demand of God's Prophet Ibrahim, peace be upon him, as he said: ("Lord! Make this a secure land, and provide its population with (various) products, such of them as believe in Allah and the Last Day." He said, "And whoever disbelieves, I will make him enjoy a little, thereafter I will constrain him to the torment of the Fire-and how miserable is the Destiny!" (The Cow: 162). The Almighty also showed that security is one of the graces of God that God has bestowed upon Quraysh as He says (For the (customary) accord (Or: joining together) of Quraysh, So let them worship The Lord of this House, Who has fed them against hunger and secured them from fear).

The Prophet, peace and blessings of God be upon him, made security one of the three basic elements of life. So, he said: (Whoever begins the day feeling family security and good health; and possessing provision for his day is as though he possessed the whole world) (Compiled by Ibn Majah) (Shaldan, 2013).

In terms of the emergence of this concept of intellectual security at this present time, its emergence may have multiple reasons, and perhaps the most important of these reasons is embracing extremist ideas, departing from moderation. Then, the tendency to violence and aggression, destruction, and unlawful killing of souls, intimidation and terror of the safe, and the expiation of others in their doctrines and beliefs, which has been known by the term (terrorism), one of the modern terms with motives that led to its occurrence. Manifestations of exaggeration, inflexible application of religion and absence of moderation in the human personality are what led it to the extremism that inspires terrorism, as it is its origin and source.

Extremism and terrorism are two phenomena of intellectual deviation and human behavior that lacks right guidance and moderation, and tends to be violent and aggressive towards nature and towards other human beings (Al-Swailem, 2009; Mbarki, 2009).

It is noteworthy that the intellectual deviation is the tendency to not be right in the fundamentals of religion in what the mind produces in terms of opinion, and it is a disorder in the mind and thought of man (Al-Awaji, 2009).

Extremism is defined as: "Transcending the limit and exaggeration in religion, which is domination in it and extremism until it exceeds the limit. It transcends moderation and the necessity of its part away from the efforts and moderate approaches of the nation (Al-Saghir \& Al-Zamzami, 2009).

As for the definition of the concept of terrorism, there have been many opinions about the definition of this concept. However, Al-Sudais (2009) stated, "I think that the comprehensive definition that gathers terrorism its parties and organizes in concluding its objectives is consistent with the principles of Sharia, which is subject to its terms, and the definition of the Fiqh Council of the Muslim World League, which is the aggression that individuals, groups, or states perform against a person, in his religion, blood, reason, property and honor, and includes types of intimidation, harm, threats and unlawful killing.

Terrorism as a concept of behavior has been addressed in psychology literature. Mansour and Al-Sharbini (2003) stated that terrorism is a disordered behavior carried out by an individual or group, and this terrorist behavior is characterized by violence and aggression in multiple physical or moral forms, and aims to influence individuals, groups, or governments in directions that may not be normal, followed by the creation of a climate of unrest and imbalances, which would undermine security. 
From another connotation, Mubaraki (2009) emphasized that terrorism is a phenomenon that has emerged during the past years from which the countries of the world have suffered as a result of the intellectual and behavioral deviations far from the concepts of Islam and the purposes of the tolerant Sharia. So, it lacked the (moderation) that God has assigned to this nation, the Almighty said (And thus we have made you a middle nation to be witnesses over mankind, and (for) the Messenger to be a witness over you.) (The Cow: 143)

Badawi (2017) stated that moderation is the benevolence of this nation, and the nation is still fine as long as it preserves this characteristic of moderation, which represents fairness and righteousness on the paths of God Almighty, and if it deviates from moderation to one side of it, it neglects or exaggerates then it has perished, then extremism is peril.

\section{The Concept of Moderation:}

Scholars and researchers have differed among themselves in formulating the definition of moderation, even if what is meant in the end is the same, and it is possible to adopt the definition presented by Al-Saudi (2008), which believes that it requires all meanings from the parts of moderation, as he stated that moderation in the common custom in our time means moderation, belief, attitude and behavior. There is no exaggeration in religion, no extremism or deviation in belief, no complacency or negligence, no arrogance, no submission, no humiliation, no surrender, no submission and no servitude to someone other than God - the Most High - and neither hardening nor embarrassment, nor indulgence or neglecting the rights of God Almighty, not the rights of people. And in terms of the importance of moderation, Maqbool (2009) indicated that moderation is the approach of Islam in dealing with calamities and developments (as well as making you a nation of moderation) as well as in dealing with life problems, and it is a method that combines the ranks of charity, indicates moderation and promotes integrity. In addition, moderation is an intellectual and behavioral approach that balances originality with contemporariness, between capabilities and duties. It is privacy without retreat, interaction without dissolution.

Accordingly, we can say that the wrong understanding of and exaggeration in thought and belief are what created the extremist thought, and its strictness and adherence to it, and not deviating from it, which formed a subjective tendency towards extremism and delinquency due to the inclination far from moderation, and from it the extremist person can be described with many characteristics, including:

1) Intolerance for opinion and group, where the extremist believes that his ideology, race, or sect is the best and the right one.

2) Exaggeration and fanaticism in his individual opinion and not accepting dialogue. Sometimes, he thinks that he is on the right and what else is in error, and he also allows himself to strive in the most accurate jurisprudential issues, but does not allow specialized scholars of the era individually or collectively to do so. He does not recognize the existence of others, and this indicates the rigidity of the fanatic, not allowing him to see the purposes of the Sharia or the circumstances of the time, and does not allow himself to have a dialogue with them.

3) Isolation, introversion, non-involvement in society and non-dealing with others

4) Using violence roughly, as the extremist gives himself the right of guardianship over others and thus hold them accountable and in violation of his beliefs.

5) Blind imitation of the person or group to which he belongs, and therefore he does not think or strive to know the right from the wrong

6) The pessimistic theory and belittling the actions of others:

7) Impulsivity and lack of self-control.

8) Departing from good intent and moderate facilitation (Al-Sultan, Nisreen 2015)

There are psychological and social characteristics of the terrorist personality that Mahmoud (2013) mentioned that there are common psychological and social characteristics of the terrorist in any society, which are briefly defined in the following points:

- Personality disorder and extreme thinking.

- $\quad$ Misunderstanding others and interpreting their motivations negatively.

- Overestimating oneself or practicing insanity and arrogance over others.

- General disturbance of mood and a sense of constant anxiety and tension.

- Departing from social norms and underestimating the order, values, customs and traditions prevailing in 
society.

- Violation of laws with criminal precedents.

- Exercising terrorist behaviors in all their forms of oppression, violence and verbal aggression.

- $\quad$ The practice of a group of defensive tricks and being excessive in them: such as attribution and transfer. He attributes every accusation to others and justifies his behavior as being logical and rational, and his anger and hatred are transferred to another person.

- Intellectual stagnation, mental lockout, and rigidity of beliefs.

- $\quad$ Fictitious adherence to belongingness to a specific terrorist group more than adherence to a true, logical affiliation with a moderate religious belief.

Taking care of intellectual security:

There is no doubt that the extreme intellectual and behavioral deviations have security implications that impose negative trends and goals represented in destabilizing security and stability, committing criminal behavior, and other such security effects that may extend to include other types of insecurity. Hence, this matter may require finding solutions that contribute to prevention of these security effects resulting from the extremist intellectual ailments and deviations. Intellectual security is the most important treatment for confronting extremist ideas, as it is the impenetrable fence and the thin bulwark against any extremist ideology, deviating from righteousness, and confronting thought with a bright thought is the best method and curative treatment.

It should be noted here that when the thought is moderate and luminous, it is a security guardian that gives actual prosperity in practice, science, theory, practice, values and culture, but when extremist, destructive and corrupt ideas leak out and then localize and exploit certain hands that have threatening goals, the idea turns into a bomb and can lead to devastation and extremism leading to terrorism (Al-Sharif, 2013).

Over more than a decade, the International Group believed that it is necessary to reduce the elements that promote the existence and continuation of violent, unfortunate and anti-human and anti-civilization conditions that are repugnant with individual security, national security as well as international community safety. This gave rise to the seek for new security solutions and more-efficient mechanisms to maintain persons and gains and respect of human values. Therefore, there emerged the new perspective of comprehensive security that goes beyond the limits of traditional security to overlapping solutions and mechanisms for risks and threats, not through violence and oppression, but rather by responding to community requirements and security covering all components of the national group (Pository.nauss.edu.sa).

In the same context, the vision of Conference on Extremist Ideologies and Terrorism, held in Berlin, Germany (14-15 November 2019), in cooperation with the Arab Democratic Center, headquartered in the Arab Republic of Egypt - Germany, we determined. It stated that the international community defined extremism a long time ago. Its historical roots date back to the establishment of the state identity itself, where extremist political, ideological and religious sects terrified the human community to compel it to waive and submit to the demands favoring the interests of such sects impose opinion by force) (Conference on Extremist Ideologies. 2019).

From the above, it becomes clear to us the importance of intellectual security as the most important protection shield for the gains and the greatest necessities and protection from ideas and temptations that lead to the weakening and disintegration of the nation's youth, in addition to its importance in directing young people towards moderate thought and its impact on combating terrorism destabilizing the society.

From this standpoint, educational institutions are among the first parties concerned with preserving the security and protection of society from spoilage by building the personality of these young people in an Islamic manner. So, we find that when any nation or society is exposed to a crisis, it tends to education as the most appropriate approach for change and correction. Education is concerned with forming correct concepts, strengthening them in the minds of young people and protecting them from any current or ideological deviation that may occur to their behavior (Al-Anzi, 2008).

The mission of education has a lofty goal in its essence: to build the civilized human being. It is a sacred mission and a sublime profession that cares for the individual and is able to face challenges of life.

Al-Ghamdi (2006) indicates that the teaching profession in Islamic educational thought derives its origins from the Islamic faith as a holistic philosophy of life, and a profession because it requires from its owners to have knowledge, skill, a sense of honesty, a commitment to responsibility towards the educated individual and an educational philosophy to achieve the goals of society. 
Attention to preparing the teacher in the light of the demands of development and developments in the era to achieve the goals of society is a part of his basic function and responsibilities that require shaping the personalities and directing behavior of learners. So, he has a lot of educational responsibilities, as the most important element of the educational process and the guide and a major supporter of this process.

Accordingly, attention should be paid to the Islamic education teacher to properly perform his educational mission. $\mathrm{He}$ is required to develop the personality of the learner in thought and behavior. Therefore, his preparation programs must receive more attention, and this requires that his preparation programs and preparation institutions be directed towards the challenges of the age related to extremism and terrorism, through introducing the requirements of intellectual security to the preparation programs, and including its concepts in the objectives and content of those courses in order to enhance the culture of this concept.

On this basis, there are competencies that the student teacher must possess during his preparation at preparation colleges, which are competencies to which those interested in preparing it at the preparation colleges and training him during the service have indicated. It appears that the teacher's adequacy deals with theoretical and practical aspects to achieve the required goals with the ability of internal motives to achieve this, which requires special preparation for the teacher to achieve these competencies in their various forms, and from here the forms and patterns of teacher preparation, including pre-service, and in-service functioning, varied.

There is also a behavioral personal preparation and a professional academic preparation. Hence, this matter calls for preparing the teacher and enabling him to have a set of competencies that will help him achieve the goals entrusted to him, which can achieve balanced personalities in their different aspects. This, in turn, would eliminate the causes and manifestations of extremism and exaggeration in their various manifestations. That is why we find that the Islamic education teacher's enjoyment of a set of personal, specialized and cultural competencies is capable of creating balanced and moderate personalities capable of standing in front of extremist ideas, and able to judge extraneous ideas in the light of the Qur'an and Sunnah, while adhering to the values of moderation that control a Muslim's behavior with Muslims and others based on the stance of Islam towards the other. In addition, the competencies help students to face what is emerging around them and adopt the correct attitude towards it, which leads to highlighting the true essence of Islam in its correct form, away from all forms of accusations attached to Islam, especially with regard extremism, exaggeration and terrorism. (Matalqa, 2009)

\section{Previous Studies}

The researcher reviewed the legal and educational studies and research on intellectual security relevant to the current study. Despite their scarcity, what was found of it was its direction towards the legal field, including what was towards it and others towards the educational field within the limits of (the researcher's knowledge). These studies and research have come on as follows:

First: Studies related to the legal field:

Al-Qarni (2009) entitled "The Role of Universities in Guiding Students towards Moderation", the study's objectives and directions focused on the importance of directing young people towards moderate thought to protect them against intellectual deviation. The study reached several results, the most important of which are: The university professor has an important role in inculcating correct concepts in the minds of young people, with its intellectual immunity and security awareness to preserve components, and activate the role of scientific research in the fields of achieving intellectual security and preventing terrorism, through research centers, courses and workshops.

Al-Awaji (2009) entitled "The efforts of the Islamic University in tackling terrorism intellectually", most of the study's objectives and directions were about intellectual security, its importance and the means to achieve it. The study focused on the importance of intellectual treatment and the university's role in confronting perverted thought with sound thought through enhancing intellectual security, raising the spirit of tolerance, consolidating the values of tolerance, and spreading the spirit of disagreement and the culture of dialogue.

Al-Sudais (2009) entitled: “Terrorism in the light of the Holy Qur'an and Sunnah, Problem and Solution.” The researcher indicated that there are grounds for terrorism, the most important of which are: ignorance of religion and the purposes of Shariah, and intellectual deviation. The researcher focused on the importance of caring for intellectual security. The study reached several recommendations, mainly activating the impact of educational thinkers and all educational institutions and their effective role in protecting the intellectual security of society as the most important bulwark in the fight against terrorism, the establishment of centers, research and studies, and the holding of sessions and conferences.

Al-Ghafili's (2009) study entitled: "Intellectual Emptiness and its Role in the Negative Impact of Means of 
Technology and Communication on the Intellectual Security of the Society", the study aimed to shed light on the seriousness of the environmental gulf, which consists of: (young people who are empty of thought, and those with stray thought seeking to spread it, in addition to the existence of a means for convergence and communication and its availability in the hands of both groups). The direction of the study was towards intellectual security as a requirement and goal of protection from intellectual emptiness. The study reached several recommendations, including: Qualifying and accustoming the youth to reading, acquaintance and deduction to give them the necessary competence to distinguish between useful ideas and stray ideas, and to emphasize the importance of sensing the dangers arising from misuse of technology.

Second: Studies related to the educational field:

Al-Melhem's (2009) study entitled: “Universities and the Intellectual Security Industry (a sociological reading of the relationship between universities and intellectual security in Saudi society). The study's direction was about the importance of the role of Saudi universities in achieving intellectual security and revealing the level of realization of its components. The study reached several recommendations, mainly: The dedication of cultural activities in the university community and their multiplicity in terms of the quality of ideas and trends, that the dialogue curriculum is available to everyone, focus on cultural and social values, cultivate a sense of belongingness and social justice among students, the role of the university professor in achieving educational goals, and the university's reliable role in terms of analyzing and studying, and analyzing the results of, societal phenomena.

Kafi's (2009) study entitled: "The role of educational curricula in establishing intellectual security - the curriculum of monotheism in the secondary stage in the Kingdom of Saudi Arabia as an example". The study aimed to explain the role of monotheism in enhancing intellectual security, and the direction of the study was to analyze the content of the curriculum of monotheism to see the extent of its inclusion of the concepts of intellectual security. The study reached several results, the most important of which is the existence of a significant amount of knowledge that would contribute to building a sound thought and achieve intellectual security. A major recommendation of the study is the importance of the correct belief and the role of academic curricula and courses in enhancing intellectual security.

Al-Noah (2011) entitled: "A proposed role for the family in Riyadh to protect its children from intellectual deviation." The study aimed to identify the internal and external role of the family to protect children from intellectual deviation, and know the requirements for activating the role from the point of view of parents. Major recommendations of the study included: Introducing the proposed matrix of roles for the family on a large scale to Shariah, educational, and psychological specialists in order to benefit from their directives towards this matrix, and to conduct an integrated awareness program on moderation and intellectual deviation.

Shaldan (2013) entitled: "The role of colleges of education at Palestinian universities in enhancing the intellectual security of their students and the means of activating it." The study's objectives and directions were about revealing the degree of colleges' practice to enhance intellectual security among their students. The study reached several findings, mainly the students' estimates about the role of colleges in enhancing intellectual security among their students, reached a rate of $(72.23 \%)$, and the study recommended the necessity of activating the role of colleges to enhance intellectual security to immunize young people from stray thought and empower teaching staff to play their role in directing them towards sound and safe ideas, and to empower and encourage students to participate in activities aiming to enhance intellectual security.

\section{Feedback and Comment on Previous Studies}

Through a review of previous studies, it is clear that the purpose of conducting these studies is to identify intellectual security and the causes of deviation of thought leading to extremism and terrorism, and the role of universities and educational institutions in confronting these phenomena and immunizing youth from stray thought. There were points of disagreement and agreement between all studies in their legal and educational fields in terms of their goals, trends, and objectives. So, the direction of the study (Al-Qarni, 2009) was about the role of universities in guiding students towards moderation for protection against intellectual deviation, while the direction of the study (Al-Awaji, 2009) was about addressing intellectual deviation and confronting deviant thought with sound thought through enhancing intellectual security, fostering a spirit of tolerance and consolidating values and a culture of dialogue among the youth. As for the study (Al-Sudais, 2009), it was directed towards the importance of caring for intellectual security, and activating the impact of thinkers, educators and educational institutions in security protection on the fact that this is the most important bulwark in the fight against terrorism, while it was directed towards the study (Al-Ghafili, 2009) towards intellectual security, as a requirement for protection from the intellectual emptiness, highlighting the danger of the environmental mixture, sensing the 
dangers arising from the use of technology, and the importance of distinguishing between useful ideas and stray ones.

As for the disagreement and agreement between studies in the educational field, the direction of the study (Al-Melhem, 2009) was about the importance of the role of Saudi universities in achieving intellectual security and revealing the level of achieving its components in terms of the quality of ideas, trends and method of dialogue, while, it was in the study (Kafi, 2009) towards analyzing the content of the unification course at the secondary stage by identifying the inclusion of concepts of intellectual security, and the extent to which the content contributes to building a sound thought. As for the study (Al-Noah, 2011), its objectives and directions were to identify the internal and external role of the family to protect children from intellectual deviations, while the objectives and trends of the study (Sheldan, 2013) were about revealing the degree of practice of colleges of education at Palestinian universities from the point of view of students themselves about enhancing intellectual security.

In spite of the disagreement and agreement between all these studies in their legal and educational fields in terms of their goals and directions, the purposes of all these studies were directed towards intellectual security to address intellectual deviations, while the current study was directed towards the reality of preparing an Islamic education teacher in the light of the requirements of intellectual security, which was not addressed in any of the previous studies. This distinguished this current study from previous studies. This current study is considered a research addition to fill the deficit in studies related to the field of specialization.

\section{Study Methodology}

The current study followed the descriptive approach, one of the methods of scientific research in terms of surveying the opinions of the teaching staff at preparation colleges on the reality of preparing an Islamic education teacher at Taibah University, in the light of the requirements of intellectual security.

Study population and sample:

The study population consists of all teaching staff at the College of Arts and the College of Education. As for the study sample, a random sample was selected from the study population, and the number of the sample members reached (83) teaching staff members, (43) teaching staff members from the College of Arts and (40) teaching staff members from the College of Education.

The following table shows the description of the study sample according to the scientific colleges:

Table 1. Distribution of the study sample according to the scientific colleges

\begin{tabular}{cccc}
\hline$\#$ & Scientific Colleges & Number & $\%$ \\
\hline 1 & College of Arts & 43 & $51.81 \%$ \\
2 College of Education & 40 & $48.19 \%$ \\
Total & 83 & $100.00 \%$ \\
\hline
\end{tabular}

Study Tool:

To verify the purposes of the study, the researcher prepared a study tool, which is a questionnaire to measure the opinions of teaching staff at preparation colleges on the reality of the Islamic Education Teacher Preparation Program in the light of the requirements of intellectual security, through a review of educational literature as well as previous research and studies related to the current study. There are two main axes, with a number of phrases falling under each. The phrases in their initial form reached (43) phrases, and to verify their authenticity, they will be presented to a group of juries to have their views on the questionnaire.

\section{Tool Validation:}

To verify the validity of the questionnaire, it was presented to a group of (10) juries, in order to express their opinions and observations on the following: Identify the extent of the questionnaire's affiliation to their main axes, the extent of the linguistic and scientific validity of the phrases of the two axes, and make deletions and additions as they may deem appropriate.

In the light of the opinions and remarks of the juries, some phrases have been modified and some words that lead to the same meaning have been deleted, and the questionnaire has become ready in its final form. The total phrases of the questionnaire in its final form reached (42) phrases that came as follows:

The first axis: the number of its phrases is (25) phrases, while the second axis has (17) phrases. 
The following is a presentation of the scale (questionnaire) distribution directed to the sample of teaching staff, and the following table explains that:

Table 2. Distribution of the scale for the study questionnaire directed at the teaching staff sample

\begin{tabular}{ccc}
\hline Agree & Agree to some extent & Do not agree \\
\hline 3 & 2 & 1 \\
\hline
\end{tabular}

In this way, the degree of intellectual security requirements for academic preparation programs (specialized cultural - educational "professional") to confront extremism and terrorism was determined, and the proposed solutions to confront the obstacles that prevent the fulfillment of the requirements of intellectual security in the programs of preparation colleges to confront extremism and terrorism by calculating the arithmetic mean for each item are set as follows:

Range $=($ Agree $3-$ Minimum Score 1$)=2$

And category length $=($ range $/$ number of classes $=2 / 3=0.66$ ), so the items are calculated as follows:

1) Items that obtain an arithmetic mean from (1 to less than 1.66) correspond to a score of disagree.

2) Items that obtain an arithmetic mean from (1.66 to less than 2.32) correspond to a degree of agree to some extent.

3) The items that obtain an arithmetic mean from (2.32 to 3.00) correspond to a degree of approval.

The researcher used statistical analysis to confirm the validity of the questionnaire in its actual form through the validity of the content, i.e. the relationship of the phrases to the fields of the questionnaire, as well as the internal consistency between the items of the questionnaire with the total questionnaire as a whole, and its stability using the Cronbach's alpha parameter, through a random sample of (25) teaching staff members from the study population.

Stability of Questionnaire:

To extract the calculation of the stability of questionnaire coefficient, the Cronbach's alpha correlation coefficient was used, and the following table shows that.

Table 3. Cronbach's alpha correlation coefficient to calculate the stability of complete questionnaire and its two axes

\begin{tabular}{lc}
\hline \# Axis & $\begin{array}{c}\text { Cronbach's Alpha } \\
\text { Coefficient }\end{array}$ \\
\hline $\begin{array}{l}\text { The first axis: requirements for intellectual security for academic preparation programs (specialized - cultural - } \\
\text { educational "professional") to counter extremism and terrorism }\end{array}$ & 0.88 \\
$2 \begin{array}{l}\text { The second axis: the proposed solutions to confront the obstacles that prevent the fulfillment of the requirements of } \\
\text { intellectual security in the programs of preparation colleges to counter extremism and terrorism }\end{array}$ & 0.63 \\
Total of the two axes & 0.953 \\
\hline
\end{tabular}

The table shows the Cronbach's coefficient, as its values were 0.63 and 0.88 respectively for the two axes of the questionnaire, and the whole questionnaire reached 0.953 . These values are considered high, which indicates that the stability is high for the two axes, and the tool as a whole, so the questionnaire and axes are applicable.

Study Output:

To answer the study's first question, which reads: "What are the requirements of intellectual security necessary for programs to prepare Islamic education teachers to confront extremism and terrorism?"

The researcher reviewed the literature, studies and research related to the current study as a study (Suwailem, 2009; Matalqa, 2009; Muhammad, 2009; Shaldan, 2013), and through which the researcher concluded that the requirements of intellectual security necessary for the teacher of Islamic education, which can be identified through the two axes of the first study, which is the "the reality of programs for preparing Islamic education teachers, academic, specialized, cultural, and professional "educational" in the light of the requirements of intellectual security to confront extremism and terrorism from the point of view of the teaching staff at preparation colleges, and the number of its phrases reached (25) phrases. The second axis is the proposed solutions to 
overcome obstacles, which prevent the fulfillment of the requirements of intellectual security in the programs of preparing Islamic education teachers to confront extremism and terrorism from the point of view of the teaching staff at preparation colleges, and the number of its phrases reached (17) phrases.

To answer the second study question, which reads: What is the reality of programs for preparing Islamic education teachers in the light of the requirements of intellectual security to confront extremism and terrorism from the point of view of the teaching staff at preparation colleges? The arithmetic means, standard deviations and percentages have been extracted, and the following table answers this question.

Table 4. Descriptive data for the first axis: the reality of programs for preparing Islamic education teachers, academic, specialized, cultural, and professional "educational" in the light of the requirements of intellectual security to confront extremism and terrorism from the point of view of teaching staff at preparation colleges

\begin{tabular}{|c|c|c|c|c|c|c|c|c|c|}
\hline \multirow{2}{*}{ 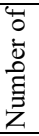 } & \multirow[b]{2}{*}{ Items } & & \multicolumn{3}{|c|}{ Score of acceptance $\mathrm{N}=83$} & \multirow{2}{*}{$\begin{array}{l}8 \\
\frac{\pi}{\pi} \\
\frac{\pi}{0} \\
\sum\end{array}$} & \multirow{2}{*}{ 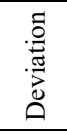 } & \multirow[b]{2}{*}{ ¿̊ } & \multirow{2}{*}{ 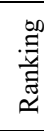 } \\
\hline & & & Agree & $\begin{array}{c}\text { Agree to } \\
\text { some extent }\end{array}$ & Do not agree & & & & \\
\hline \multirow{2}{*}{1} & \multirow{2}{*}{$\begin{array}{l}\text { Preparation programs define the roles } \\
\text { required to maintain homeland } \\
\text { security. }\end{array}$} & $\mathrm{K}$ & 58 & 22 & 3 & \multirow{2}{*}{2.66} & \multirow{2}{*}{0.55} & \multirow{2}{*}{$88.76 \%$} & \multirow[t]{2}{*}{1} \\
\hline & & $\%$ & 69.88 & 26.51 & 3.61 & & & & \\
\hline \multirow{2}{*}{2} & Preparation programs illustrate the & $\mathrm{K}$ & 54 & 26 & 3 & \multirow[t]{2}{*}{2.61} & \multirow[t]{2}{*}{0.56} & \multirow[t]{2}{*}{$87.15 \%$} & \multirow[t]{2}{*}{2} \\
\hline & downsides of intellectual deviation & $\%$ & 65.06 & 31.33 & 3.61 & & & & \\
\hline \multirow[b]{2}{*}{3} & & $\mathrm{~K}$ & 45 & 31 & 7 & \multirow[t]{2}{*}{2.46} & \multirow[t]{2}{*}{0.65} & \multirow{2}{*}{$81.93 \%$} & \multirow[t]{2}{*}{4} \\
\hline & $\begin{array}{l}\text { students to engage in various } \\
\text { intellectual issues }\end{array}$ & $\%$ & 54.22 & 37.35 & 8.43 & & & & \\
\hline \multirow{2}{*}{4} & Preparation programs develop skills for & $\mathrm{K}$ & 32 & 45 & 6 & \multirow[t]{2}{*}{2.31} & \multirow[t]{2}{*}{0.60} & \multirow[t]{2}{*}{$77.11 \%$} & 11 \\
\hline & $\begin{array}{l}\text { dialogue and intellectual } \\
\text { communication }\end{array}$ & $\%$ & 38.55 & 54.22 & 7.23 & & & & \\
\hline 5 & Preparation programs show students & $\mathrm{K}$ & 32 & 45 & 6 & 2.31 & 0.60 & $77.11 \%$ & 11 \\
\hline 3 & the skill of scientific thinking & $\%$ & 38.55 & 54.22 & 7.23 & & & & \\
\hline & Preparation programs highlight the role & $\mathrm{K}$ & 44 & 38 & 1 & 2.52 & 0.53 & $83.94 \%$ & 3 \\
\hline 0 & of faith in guiding correct thought & $\%$ & 53.01 & 45.78 & 1.20 & & & & \\
\hline & Preparation programs present a topic & $\mathrm{K}$ & 40 & 39 & 4 & 2.43 & 0.59 & $81.12 \%$ & 5 \\
\hline r & on moderate Islamic thought & $\%$ & 48.19 & 46.99 & 4.82 & & & & \\
\hline$Q$ & Preparation programs present examples & $\mathrm{K}$ & 32 & 43 & 8 & 2.29 & 0.63 & $76.31 \%$ & 13 \\
\hline 0 & of positive currents of thought & $\%$ & 38.55 & 51.81 & 9.64 & & & & \\
\hline & Preparation programs direct students to & $\mathrm{K}$ & 31 & 47 & 5 & & & & \\
\hline 0 & reading books related to the & & & & & 2.31 & 0.58 & $77.11 \%$ & 11 \\
\hline 9 & jurisprudence of calamities & $\%$ & 37.35 & 56.63 & 6.02 & & & & \\
\hline & Preparation programs develop the & $\mathrm{K}$ & 30 & 50 & 3 & 2.33 & 0.54 & $77.51 \%$ & 10 \\
\hline 10 & $\begin{array}{l}\text { ability to distinguish between true and } \\
\text { false }\end{array}$ & $\%$ & 36.14 & 60.24 & 3.61 & & & & \\
\hline & Preparation programs are concerned & $\mathrm{K}$ & 35 & 44 & 4 & 2.37 & 0.58 & $79.12 \%$ & 7 \\
\hline 11 & $\begin{array}{l}\text { with developing students' citizenship } \\
\text { values }\end{array}$ & $\%$ & 42.17 & 53.01 & 4.82 & & & & \\
\hline & Preparation programs present topics & $\mathrm{K}$ & 39 & 38 & 6 & 2.40 & 0.62 & $79.92 \%$ & 6 \\
\hline 12 & $\begin{array}{l}\text { related to community issues and } \\
\text { problems }\end{array}$ & $\%$ & 46.99 & 45.78 & 7.23 & & & & \\
\hline & Preparation programs indicate the & $\mathrm{K}$ & 34 & 45 & 4 & 2.36 & 0.58 & $78.71 \%$ & 8 \\
\hline 13 & $\begin{array}{l}\text { importance of creating trends that } \\
\text { reinforce social belongingness }\end{array}$ & $\%$ & 40.96 & 54.22 & 4.82 & & & & \\
\hline & Preparation programs show the & $\mathrm{K}$ & 33 & 43 & 7 & 2.31 & 0.62 & $77.11 \%$ & 11 \\
\hline 14 & $\begin{array}{c}\text { importance of peace and coexistence } \\
\text { with other societies }\end{array}$ & $\%$ & 39.76 & 51.81 & 8.43 & & & & \\
\hline 15 & Preparation programs demonstrate the & $\mathrm{K}$ & 36 & 42 & 5 & 2.37 & 0.60 & $79.12 \%$ & 7 \\
\hline 15 & importance of dialogue with others & $\%$ & 43.37 & 50.60 & 6.02 & & & & \\
\hline 16 & Preparation programs encourage a safe & $\mathrm{K}$ & 29 & 46 & 8 & 2.25 & 0.62 & $75.10 \%$ & 15 \\
\hline
\end{tabular}




\begin{tabular}{|c|c|c|c|c|c|c|c|c|c|}
\hline & openness to other cultures & $\%$ & 34.94 & 55.42 & 9.64 & & & & \\
\hline \multirow[b]{2}{*}{17} & Preparation programs encourage & $\mathrm{K}$ & 37 & 42 & 4 & 2.40 & 0.58 & $79.92 \%$ & 6 \\
\hline & $\begin{array}{l}\text { students on the importance of linking } \\
\text { originality with contemporary life }\end{array}$ & $\%$ & 44.58 & 50.60 & 4.82 & & & & \\
\hline \multirow[b]{2}{*}{18} & Preparation programs for students & $\mathrm{K}$ & 30 & 44 & 9 & 2.25 & 0.64 & $75.10 \%$ & 15 \\
\hline & $\begin{array}{l}\text { demonstrate the importance of the } \\
\text { media in the combat against extremism }\end{array}$ & $\%$ & 36.14 & 53.01 & 10.84 & & & & \\
\hline \multirow[b]{2}{*}{19} & Preparation programs present topics of & $\mathrm{K}$ & 32 & 48 & 3 & 2.35 & 0.55 & $78.31 \%$ & 9 \\
\hline & interest in Islamic heritage & $\%$ & 38.55 & 57.83 & 3.61 & & & & \\
\hline \multirow{2}{*}{20} & Preparation programs direct students & $\mathrm{K}$ & 24 & 48 & 11 & 2.16 & 0.63 & $71.89 \%$ & 17 \\
\hline & towards self-learning & $\%$ & 28.92 & 57.83 & 13.25 & & & & \\
\hline \multirow[b]{2}{*}{21} & Preparation programs use instructional & $\mathrm{K}$ & 32 & 50 & 1 & 2.37 & 0.51 & $79.12 \%$ & 7 \\
\hline & $\begin{array}{l}\text { strategies that develop students' } \\
\text { thinking skills }\end{array}$ & $\%$ & 38.55 & 60.24 & 1.20 & & & & \\
\hline \multirow{2}{*}{22} & Preparation programs direct students & $\mathrm{K}$ & 25 & 51 & 7 & 2.22 & 0.59 & $73.90 \%$ & 16 \\
\hline & towards creativity and innovation & $\%$ & 30.12 & 61.45 & 8.43 & & & & \\
\hline \multirow[b]{2}{*}{23} & Preparation programs illustrate the & $\mathrm{K}$ & 28 & 51 & 4 & 2.29 & 0.55 & $76.31 \%$ & 13 \\
\hline & $\begin{array}{l}\text { educational role of immunizing } \\
\text { emerging intellectual currents }\end{array}$ & $\%$ & 33.73 & 61.45 & 4.82 & & & & \\
\hline \multirow[b]{2}{*}{24} & Preparation programs demonstrate the & $\mathrm{K}$ & 27 & 51 & 5 & 2.27 & 0.56 & $75.50 \%$ & 14 \\
\hline & $\begin{array}{l}\text { impact of the media invasion on the } \\
\text { social order }\end{array}$ & $\%$ & 32.53 & 61.45 & 6.02 & & & & \\
\hline \multirow{5}{*}{25} & Preparation programs demonstrate the & $\mathrm{K}$ & 30 & 48 & 5 & & & & \\
\hline & $\begin{array}{l}\text { importance of dissolving differences } \\
\text { and rejecting doctrinal fanaticism }\end{array}$ & $\%$ & 36.14 & 57.83 & 6.02 & 2.30 & 0.58 & 76.71 & 12 \\
\hline & Average total for the first axis & & \multicolumn{7}{|c|}{2.36} \\
\hline & Standard deviation & & \multicolumn{7}{|c|}{0.59} \\
\hline & $\%$ & & \multicolumn{7}{|c|}{$78.55 \%$} \\
\hline
\end{tabular}

Table 4 shows the descriptive data in terms of frequencies, percentages, arithmetic means, standard deviation, and the ranking of the study sample responses for the first axis, the reality of programs for preparing Islamic education teachers (specialized - cultural - educational "professional") in the light of the requirements of intellectual security to confront extremism and terrorism from the point of view of the teaching staff at the preparation colleges, and the results of the largest repetition of the axis came in the phrase No. (1), which reads: "Preparation programs define the roles required to maintain homeland security" with a percentage of $(69.88 \%)$ and repeated (58) in the answer I agree, and the lowest percentage in the two phrases No. (6 and 21), "Preparation programs highlight the role of faith in guiding correct thought" The phrase "Preparation programs use instructional strategies that develop students' thinking skills", with a percentage of $(1.20 \%)$ and a repetition of (1) in the answer, I disagree. In terms of ranking, the phrase No. (1) came in the first ranking of the axis with an arithmetic mean of (2.66) and a percentage of $(88.76 \%)$. Phrase No. (20) came in the last ranking of the axis with an arithmetic mean of (2.16) and a percentage of $(71.89 \%)$, while the arithmetic mean of the axis reached (2.36), a standard deviation of $(0.59)$, and a percentage of $(78.55 \%)$, meaning the reality of programs for preparing Islamic education teachers in the light of the requirements of intellectual security to confront extremism and terrorism from the point of view of the teaching staff at the preparation colleges.

It is evident from the results in Table 4 that the highest percentage for the first axis in terms of ranking came to phrase No. (1), which reads: (Preparation programs define the roles required to maintain homeland security) and its percentage reached (88.76\%) hitting the first, followed by Phrase No. (2) which reads: (Preparation programs illustrate the negatives of intellectual deviation) with a percentage of $(87.15 \%)$, followed by phrase No. (6), reading (Preparation programs highlight the role of faith in guiding correct thought) in the third place with a percentage of (83.94\%), and in the last ranking came the two phrases No. (20 and 22), with a percentage of (71.89\%) for phrase No. (1), and a percentage of (73.90\%) for phrase No. (22).

These results, which made it clear that the preparation programs clarify the roles required to maintain the security of the homeland, can be attributed to the study sample's vision of the importance of homeland security, which, they believe, is not surpassed by any other consideration, making them unanimously agreeing on this vision, giving this 
phrase the first rank.

In terms of phrase No. (2) obtaining the second place, this may also be due to the study sample's vision of the negatives of intellectual deviation that may affect the security of the homeland, which may cause security and instability as a result of the intellectual deviation leading to extremism and destruction.

This finding accords with the findings of the study conducted by (Al-Melhem, 2009). It showed the universities' role in achieving intellectual security and instilling dialogue and its importance in enhancing the values of peaceful and international coexistence among the world's peoples.

As for phrase No. (6) obtaining the third rank, this reason may be attributed to the study sample's belief in the importance of the role of belief in directing the mind towards sound thinking and protecting it from extremist ideas that may negatively affect the belief. This result is consistent with the results of the study (Sheldan, 2013).

It showed the important role of colleges to enhance intellectual security and protect young people from false thought, positively reflecting on national security and global peace.

Regarding phrase No. (20) which reads: (Preparation programs direct students towards self-learning) and obtaining the last rank, this may be due to the feeling and belief of the study sample members that self-learning is not important in terms of guiding the student and protecting them from intellectual deviation, and that its importance may lie in directing the learner towards achieving and developing their scientific thinking skills. This result also agrees with the result of phrase No. (22), which reads: (Preparation programs direct students towards creativity and innovation), and this dragged the two phrases No. (20-22) to the last ranks.

To answer the question of the third study, which reads: "What are the proposed solutions to overcome the obstacles that prevent the fulfillment of the requirements of intellectual security in the programs of preparing Islamic education teachers to confront extremism and terrorism from the point of view of the teaching staff at preparation colleges". Arithmetic means, standard deviations and percentages have been extracted and the following table shows that:

Table 5. Descriptive data for the second axis (The proposed solutions to overcome the obstacles that prevent the fulfillment of the requirements of intellectual security in the programs of preparing Islamic education teachers to confront extremism and terrorism from the point of view of the teaching staff at preparation colleges)

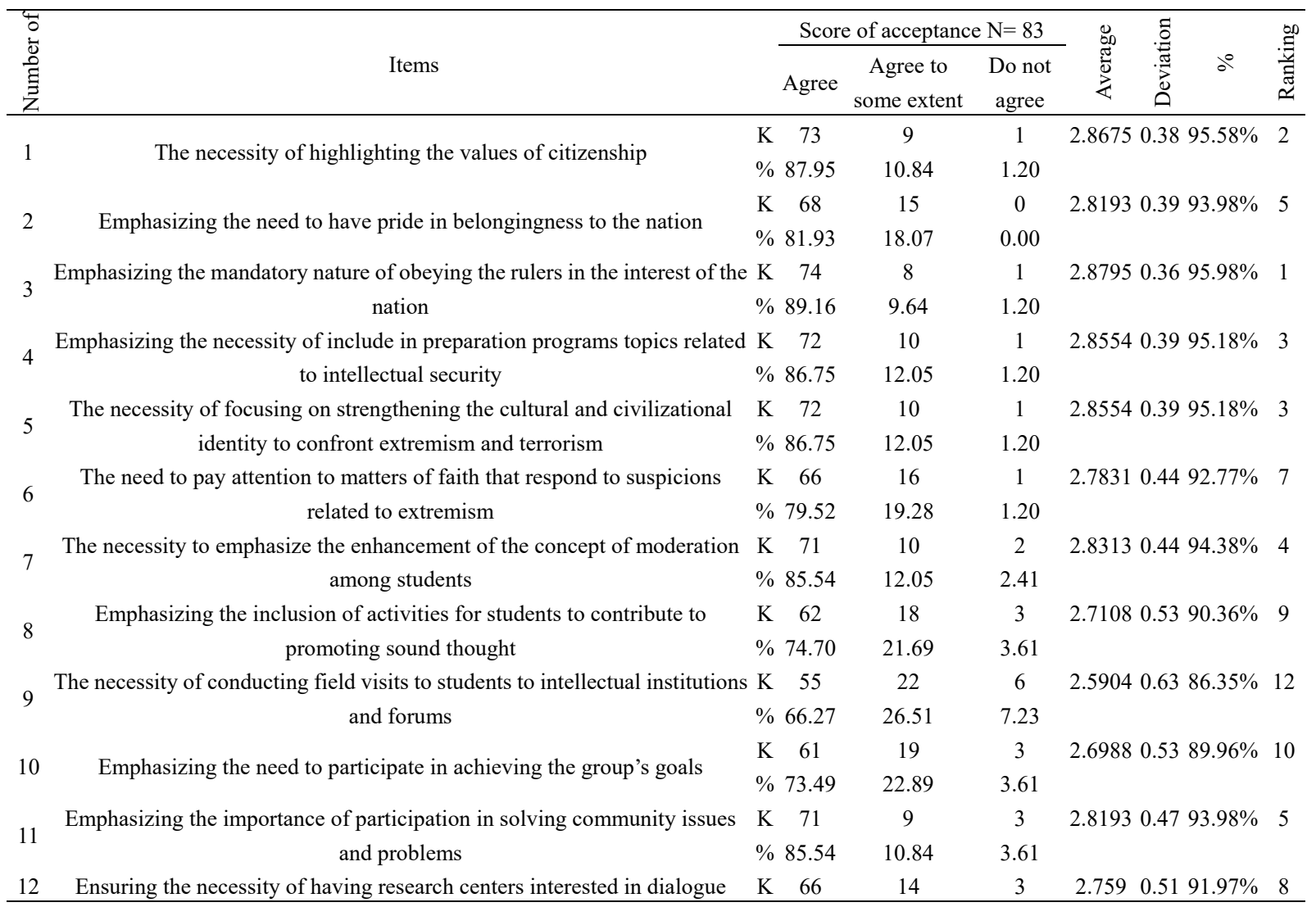




\begin{tabular}{|c|c|c|c|c|c|c|}
\hline & & $\% 79.52$ & 16.87 & 3.61 & & \\
\hline \multirow{2}{*}{13} & Emphasizing the importance of respecting and coexisting with others & K 75 & 5 & 3 & $2.86750 .4495 .58 \%$ & 2 \\
\hline & peacefully & $\% 90.36$ & 6.02 & 3.61 & & \\
\hline \multirow{2}{*}{14} & Emphasizing the importance of developmental and preventive education to & K 69 & 11 & 3 & $2.79520 .4993 .17 \%$ & 6 \\
\hline & address intellectual deviation & $\% 83.13$ & 13.25 & 3.61 & & \\
\hline \multirow{2}{*}{15} & Emphasizing the importance of reading psychology theories that & K 62 & 14 & 7 & $2.66270 .6388 .76 \%$ & 11 \\
\hline & demonstrate the psychological and social personality of the terrorist & $\% 74.70$ & 16.87 & 8.43 & & \\
\hline \multirow{2}{*}{16} & Emphasizing on holding scientific courses on how to manage and understand & $\mathrm{K} \quad 71$ & 10 & 2 & $2.83130 .4494 .38 \%$ & 4 \\
\hline & verses of the Holy Qur'an, and make it a behavior and action & $\% 85.54$ & 12.05 & 2.41 & & \\
\hline \multirow{5}{*}{17} & Emphasizing the seriousness of the inflammatory information reported on & K 71 & 9 & 3 & $2.81931 .6293 .98 \%$ & 5 \\
\hline & the Internet & $\% 85.54$ & 10.84 & 3.61 & & \\
\hline & Average total for the second axis & & & \multicolumn{2}{|c|}{2.79} & \\
\hline & Standard deviation & & & \multicolumn{2}{|c|}{0.53} & \\
\hline & $\%$ & & & \multicolumn{2}{|c|}{$93.03 \%$} & \\
\hline
\end{tabular}

Table 5 above shows the descriptive data in terms of frequencies, percentages, arithmetic means, standard deviation, and the ranking of the study sample responses for the second axis, proposed solutions to overcome the obstacles that prevent the fulfillment of the requirements of intellectual security in programs to prepare Islamic education teachers to confront extremism and terrorism from the point of view of teaching staff at preparation colleges. The results of the largest repetition of the axis came in the phrase No. (13), which reads: "Emphasizing the importance of respecting and coexisting with others peacefully" with a percentage of $(90.36 \%)$ and repeatedly (75) in the answer I agree, and the lowest percentage was in phrase No. (2)), which stipulates "the need to have pride in belongingness to the nation's entity" with a percentage of $(0.00 \%)$ and a repeat of $(0)$ in the answer, I disagree, and in terms of order, the phrase No. (3) came in the first order of the axis with an arithmetic mean of (2.8795) and a percentage of (95.98\%), and the phrase No. (9) came in the last ranking of the axis with an arithmetic mean of (2.5904) and a percentage of $(86.35 \%)$, while the arithmetic mean of the axis was (2.79) and a standard deviation of $(0.53)$ and a percentage of $(93.03 \%)$ i.e. as to the degree of proposed solutions to overcome the obstacles that prevent the fulfillment of the requirements of intellectual security in the programs to prepare Islamic education teachers to confront extremism and terrorism from the point of view of the teaching staff at preparation colleges.

It is evident from the results in Table 5 that the highest percentage for the second axis in terms of ranking came to phrase No. (3), which reads (Emphasizing the mandatory nature of obeying the rulers in the interest of the nation), and its percentage reached (95.98\%), coming in the first rank, followed by the phrase No. (1) which reads: (The necessity of highlighting the values of citizenship), with a percentage (95.58\%), then in the third place, the two phrases No. (4.5) with a frequent rate of $(95.18 \%)$. 4) on (emphasizing the need to include in preparation programs topics related to intellectual security), and phrase No. (5) reads (The necessity of focusing on strengthening the cultural and civilizational identity to confront extremism and terrorism), and in the last rank came the phrase No. (9), which reads: (The necessity of field visits to students to intellectual institutions and forums).

These results that showed that the preparation programs that emphasize the necessity of obedience to the rulers in the interest of the homeland can be accounted to the vision of the study sample that the importance of the necessity of obedience to the guardian whose obedience was ordinated by God Almighty as the Almighty said: (And obey God and obey the Messenger and the ruler of you). This formed among the sample members the conviction that obedience to the rulers is mandatory and that it establishes security and stability, preserves the five necessities and warding off evil, which made this phrase occupy the first ranking.

As for phrase No. (1) obtaining the second place, this may be due to the individuals' belief in the importance of highlighting citizenship values for preparation programs, as this is to protect and reinforce the requirements beside being a basic pillar of intellectual security.

With regard to the results of the two phrases No. (4 and 5), the reason for this may be due to the study sample's perception of the importance of including intellectual security requirements in the preparation programs, which developed a sense of the importance of these requirements for intellectual security as they lead to strengthening the student's identity and lead to his awareness of the means to avoid falling a prey to intellectual deviations and protecting them from being dragged into extremism and terrorism.

As for phrase No. (9), obtaining the last rank, this may be due to the sample members' belief that field visits to students to intellectual institutions and forums are not serious, or they may believe that these roles are entrusted to 
them and that there is no need for such intellectual visits and forums. All programs that are offered to students through teaching courses, dialogues, seminars, or workshops that take place at the university are capable of creating an open and sound thought among students, which is why this phrase occupies the last place in terms of ranking.

In terms of calculating the ranking of the study axes, the arithmetic means, standard deviations and percentages of each axis were extracted from the study axes. The following table shows that.

Table 6. The descriptive data for the first and second axes of study

\begin{tabular}{|c|c|c|c|c|c|}
\hline \# & Axis & Number & $\begin{array}{c}\text { Arithmetic } \\
\text { mean }\end{array}$ & $\%$ & Ranking \\
\hline 1 & $\begin{array}{l}\text { The first axis: the reality of programs for preparing Islamic education teachers in the } \\
\text { light of the requirements of intellectual security to confront extremism and terrorism } \\
\text { from the point of view of the teaching staff at preparation colleges }\end{array}$ & 83 & 2.36 & $78.55 \%$ & 2 \\
\hline 2 & $\begin{array}{l}\text { The second axis: the proposed solutions to overcome the obstacles that prevent the } \\
\text { fulfillment of the requirements of intellectual security in the programs of preparing } \\
\text { Islamic education teachers to confront extremism and terrorism from the point of view } \\
\text { of the teaching staff at preparation colleges }\end{array}$ & 83 & 2.79 & $93.03 \%$ & 1 \\
\hline
\end{tabular}

The table shows the results of the arithmetic mean and percentage of the reality of programs for preparing Islamic education teachers in the light of the requirements of intellectual security from the point of view of the teaching staff at preparation colleges, where the results were as follows:

- The second axis came in the first rank with a percentage of (93.03\%).

- $\quad$ There came in the second rank the first axis, with a percentage of (78.55\%).

In terms of this result, the reason for obtaining the second axis in the first ranking may be due to the study sample's vision of the importance of intellectual security requirements, and then developing proposed solutions to overcome any obstacle facing the preparation programs as they represent the academic and intellectual building block for learners, directing them towards sound and safe thought, and immunizing them against any intellectual emptiness that could drag them into extremism and terrorism.

To answer the study's fourth question, which reads: "Are there statistically significant differences at the significance level $(0.05 \geq \alpha)$ about the reality of programs for preparing Islamic education teachers in the light of the requirements of intellectual security among the study sample members of the teaching staff at preparation colleges due to the college variable. The following tables answer this question.

Table 7. Arithmetic means and standard deviations of the study sample according to the scientific college on the reality of programs for preparing Islamic education teachers in the light of the requirements of intellectual security among the members of the study sample of teaching staff members at preparation colleges

\begin{tabular}{ccccc}
\hline & Scientific College & Number & Arithmetic mean & Standard deviation \\
\hline \multirow{2}{*}{ First axis } & Educational colleges & 40 & 2.36 & 0.412 \\
& Colleges of Arts Studies & 43 & 2.35 & 0.410 \\
\hline \multirow{2}{*}{ Tool } & Colleges of Arts Studies & 40 & 106.92 & 2.17 \\
& Colleges of Arts Studies & 43 & 105.83 & 1.89 \\
\hline
\end{tabular}

It appears from the previous table that there is a difference in the arithmetic means of the responses of the study sample to the tool, and to find out if these averages are statistically significant, a test was performed on two independent samples. The results were as follows. 
Table 8. Test results of two separate samples of the reality of programs for preparing Islamic education teachers in the light of the requirements of intellectual security among the members of the study sample of the teaching staff at preparation colleges

\begin{tabular}{ccccc}
\hline Axis & Freedom scores & Variance value & Significance level & Standard error \\
\hline First axis & 81 & 0.136 & 0.892 & 0.0123 \\
Tool & 81 & 0.379 & 0.706 & 2.87 \\
\hline
\end{tabular}

** Statistical function at the significance level $(0.01 \geq \alpha)$

* Statistical function at the significance level $(0.05 \geq \alpha)$

The table shows that there is no statistically significant difference between the study sample towards the questionnaire according to the type of the scientific college, on both the first axis and on the tool as well.

To answer the fifth study's question, which reads: “Are there statistically significant differences at the significance level $(0.05 \geq \alpha)$ about the proposed solutions to overcome the obstacles that prevent the fulfillment of the requirements of intellectual security in programs to prepare Islamic education teachers to confront extremism and terrorism from the point of view of teaching staff at preparation colleges are attributable to the college variable? The following tables answer this question.

Table 9. Arithmetic means and standard deviations of the study sample according to the scientific college on the proposed solutions to overcome the obstacles that prevent the fulfillment of the requirements of intellectual security in the programs of preparing Islamic education teachers to confront extremism and terrorism from the point of view of the teaching staff at preparation colleges

\begin{tabular}{ccccc}
\hline \multirow{2}{*}{ Second axis } & Scientific College & Number & Arithmetic mean & Standard deviation \\
& Educational colleges & 40 & 2.81 & 0.372 \\
& Colleges of Arts Studies & 43 & 2.76 & 0.353 \\
\hline \multirow{2}{*}{ Tool } & Educational colleges & 40 & 106.92 & 2.17 \\
& Colleges of Arts Studies & 43 & 105.83 & 1.89 \\
\hline
\end{tabular}

It appears from the previous table that there is a difference in the arithmetic means of the responses of the study sample to the tool, and to find out if these averages are statistically significant, a test was performed on two separate samples. The results were as follows.

Table 10. Test results of two independent samples of the reality of programs for preparing Islamic education teachers in the light of the requirements of intellectual security among the members of the study sample of members of the teaching staff at preparation colleges

\begin{tabular}{ccccc}
\hline Axis & Freedom scores & Variance value & Significance level & Standard error \\
\hline Second axis & 81 & 0.587 & 0.565 & 0.04611 \\
Tool & 81 & 0.379 & 0.706 & 2.87 \\
\hline
\end{tabular}

** Statistical function at the significance level $(0.01 \geq \alpha)$

* Statistical function at the significance level $(0.05 \geq \alpha)$

The table shows that there is no statistically significant difference between the study sample towards the questionnaire according to the type of the scientific college, on both the first axis and on the tool as well.

This result, which showed the absence of statistically significant differences between the individuals of the study sample on the first and second axes, can be accounted to their belief in the importance of the requirements of intellectual security and the necessity of their availability in all programs of preparing Islamic education programs because of this benefit for students to save them from intellectual deviations, achieve their sound thought, increase their awareness of the importance of the nation's security and preserve it from any currents or deviations that undermine security and stability, and keep the homeland far and harmless from the perils of extremism and terrorism, which formed among the study sample members convictions of the importance of intellectual security requirements for all preparation programs, and find solutions to any obstacles that prevent the fulfillment of the 
intellectual security requirements of these programs.

\section{Recommendations}

In the light of the results of the current study, the researcher recommends the following:

- Emphasizing to the planners and developers of programs for preparing Islamic education teachers in its three academic aspects (the specialized - cultural - educational "professional" aspect) the necessity of reconsidering these programs to avoid their weaknesses and reinforce their strengths to be in line with the requirements of intellectual security.

- Empowering teaching staff at preparation colleges to perform their role to guide students towards sound, enlightened and safe ideas.

- Enabling and encouraging students to actively participate in the activities and dialogues related to intellectual security that take place at the university, which will promote their sound thought, and protect their cultural identity from deviation and dissolution.

- Emphasizing the establishment of research centers concerned with dialogue, intellectual and social issues, and encouraging teaching staff to actively participate in them, with the aim of enlightening students on the issues and challenges of the age.

- Emphasizing the use of teaching strategies that promote students' thinking skills, such as the skills of analysis, synthesis and conclusion, in addition to providing creative ideas and abilities that develop their minds to avoid stray thought.

- Conducting a similar study to identify the reality of preparing teachers of other specialties in the light of the requirements of intellectual security.

\section{References}

Al-Anzi, H. A. T. (2008). The School's Role in Promoting Intellectual Security for Students in the light of Contemporary Challenges. Journal of Curricula and Educational Supervision, 3.

Al-Awaji, H. H. (2009). The efforts of the Islamic University in tackling terrorism intellectually. A research presented to the Terrorism Conference between Extremism of Thought and Thought of Extremism, held at the Islamic University in Medina.

Al-Badr, B. N. (2009). The Phenomenon of Terrorism and Extremism, its Causes and the Stance of the Kingdom of Saudi Arabia. Presented to the Conference on Terrorism between Extremism of Thought and Thought of Extremism, held at the Islamic University in Medina.

Al-Bilawi, H. (2008). Total Quality of Education (1st ed.). Dar Al Masarah, Amman, Jordan.

Al-Ghafili, F. A. (2009). The Intellectual Emptiness and its Role in the Negative Impact of the Means of Technology and Communication on the Intellectual Security of the Society. A research presented to the Conference on Terrorism between Extremism of Thought and Thought of Extremism, held at the Islamic University at Madina.

Al-Ghamdi, H. A. (2006). Ethics of the Profession of the Muslim Teacher and its Impact on Congenital Education for the Individual and the Community. A paper presented to the Saudi Society for Educational and Psychological Sciences.

Al-Hamami, A. R. H. (2009). Western Terrorism between History and Reality. A research presented to the Conference on Terrorism between the Extremism of Thought and Thought of Extremism, held at the Islamic University in Medina.

Al-Harbi, J. S. (2008). The Importance of Intellectual Security. Journal of Curriculum and Educational Supervision, 3.

Al-Johani, A. Z. (2014). A proposal for the development of programs for the preparation of the teacher of Islamic education in light of the requirements of the age and its variables. A research presented to the 23rd International Scientific Conference of the Egyptian Society for Curriculum and Teaching Methods entitled "Curriculum Development" Sun from 13-14 August (2014)

Al-Melhem, B. F. (2009). A Sociological Reading of Universities' Relationship with Intellectual Security in Saudi Society. A research presented to the National Conference on Intellectual Security, "Concepts and Challenges" from 22-25 Jumada I, Prince Nayef bin Abdulaziz Chair for Intellectual Security Studies, King Saud University. 
Al-Noah, M. A. (2011). Proposed Role for the Family in Riyadh to Protect its Children from Intellectual Deviation. Al-Khaleej Al-Arabi Journal, 122.

Al-Qarni, I. (2009). The Role of Universities in Guiding Students towards Moderation. A research presented to the Conference on Terrorism between Extremism of Thought and Thought of Extremism, held at the Islamic University in Medina.

Al-Saghir, H., \& Al-Zamzami, H. (2009). Ignorance of Religion and Misunderstanding of Islamic Texts and Following Similarities thereof. A research presented to the Conference on Terrorism between the Extremism of Thought and the Thought of Extremism, at the Islamic University in Medina.

Al-Saudi, A. A. M. (2008). Purposes of Shariah in the light of the Moderation of Islam. Annals, Center for Islamic Research and Studies, National University, Malaysia.

Al-Sharif, M. (2013). Reflections by an Arab Citizen on the Concept of Comprehensive Security. Retrieved from http://ar-ar.facebook.com/notes/10151652395854292

Al-Sudais, A. A. A. (2009). Terrorism in the light of the Sunnah and the Holy Qur'an - Problem and Solution. A research presented to the Terrorism Conference between Extremism of Thought and Thought of Extremism, held at the Islamic University in Medina.

Al-Swailem, A. S. (2009). Women's Advocacy Speech to Combat Extremism and Terrorism. A research presented to the Conference on Terrorism between the Extremism of Thought and Thought of Extremism, held at the Islamic University in Medina.

Badawi, A. A. (2017). Social and emotional intelligence and ways to develop it among our children. College of Education, Imam Abdulrahman Bin Faisal University.

Bahjat, R. M. (2009). The role of the family and the school in the face of extremism and terrorism. A study presented to the terrorism conference between the extremism of thought and the ideology of extremism.

Dahawi, B., \& Hussein, S. (2009). Professional Development of Teachers, A New Approach to Education Reform. Arab Thought House, Cairo.

Ibn Manzur, M. (2002). The Arabic Language. Al-Azhar University: Dar al-Hadith.

Kafi, A. B. A. (2009). The Role of Educational Curricula in Establishing Intellectual Security, the Monotheism Curriculum in the Secondary Stage in the Kingdom of Saudi Arabia as an Example. A research presented to the First National Conference on Intellectual Security (Concepts and Challenges) held at King Saud University.

Mahmoud, M. (2013). The Terrorist's Psychological and Social Characteristics. Journal of Social Studies and Research, Al-Wadi University, 3.

Mansour, A. H., \& Al-Sharbini, Z. (2003). Human Behavior between Crime-Aggression-Terrorism (1st ed.). Dar El Fikr El Arabi, Cairo.

Maqbool, I. (2009). From Siege to Dialogue to deal with Extremism. A research presented to the Conference on Terrorism between Extremism of Thought and Thought of Extremism, held at the Islamic University in Medina.

Matalqa, A. M. (2009). The effect of the competencies of an Islamic Education Teacher to deal with Intellectual Extremism. A research presented to the Conference on Terrorism between Extremism of Thought and Thought of Extremism, held at the Islamic University in Medina.

Mbarki, D. (2009). The Philosophy of Intellectual Security in Islam. Journal of the College of Islamic Sciences, 11(19).

Mubaraki, D. (2009). The Philosophy of Intellectual Security in Islam. Journal of the College of Islamic Sciences, 11(19).

Muhammad, H. A. (2009). The Reality of Citizenship Values for National Education Curricula and the Performance of its Teachers at the Secondary Level-Analytical Study. A research presented to the Fourth Arab (First International) Scientific Conference, Education and Future Challenges, held at Suhag University, April 25-26 2009, Volume One.

Shaldan, F. (2013). The Role of Faculties of Education in Palestinian Universities in Enhancing Intellectual Security in Demand and Means of Activating it. Journal of the Islamic University for Educational and Psychological Studies, 21(1), 33-73. 
Shehata, H., Al-Najjar, Z., \& Ammar, H. (2003). Glossary of Educational and Psychological Terms (1st ed.). Lebanese Arab House, Cairo.

Sheldan, F. (2013). The Role of the Colleges of Education in Palestinian Universities in Enhancing the Intellectual Security of their Students and Ways to Activate It. Journal of the Islamic University for Educational and Psychological Studies, 21(1), 33-73.

Suwailem, A. S. (2009). The Women's Advocacy Speech to Combat Extremism and Terrorism. A study presented to the conference on terrorism between the extremism of thought and the ideology of extremism.

\section{Copyrights}

Copyright for this article is retained by the author(s), with first publication rights granted to the journal.

This is an open-access article distributed under the terms and conditions of the Creative Commons Attribution license (http://creativecommons.org/licenses/by/4.0/). 